\title{
Mechanical behavior of Deveci pear cultivar affected by maturation
}

\author{
Elçin Yeşiloğlu Cevher ${ }^{1 *}$, Yeşim Benal Öztekin ${ }^{1}$ \\ ${ }^{1}$ Ondokuz Mayis University, Faculty of Agriculture of Agricultural Machinery, Samsun - Turkey
}

\begin{abstract}
The present study examines the mechanical behavior of 'Deveci' pear cultivar produced in Turkey in terms of harvesting periods. Penetration tests were applied to the determined sides (bloom side, lateral side and stem side) of pear fruit harvested on three different maturation dates (October 5-15-25). According to the test results, it was found that harvesting period had different effects on mechanical properties of pears. Decrease was found in rupture force, rupture energy, deformation and firmness values of pears as the harvest date progressed. Rupture force values were as $52.69,45.56$ and $41.95 \mathrm{~N}$ in the first, second and third harvesting dates, respectively. Deformation was 5.57 in the first harvesting date and as $5.12 \mathrm{~mm}$ in the third harvesting date. The present study showed that firmness values of mature pear fruit were less. Firmness value was $9.59 \mathrm{~N} / \mathrm{mm}$ in the first harvesting date and $8.09 \mathrm{~N} / \mathrm{mm}$ in the third harvesting date. The highest firmness value was found on the stem side of pears.
\end{abstract}

\section{ARTICLE HISTORY}

Received: 25 September 2019

Accepted: 09 December 2019

\section{KEYWORDS}

Pyrus communis

Mechanical properties

Rupture force

Rupture energy

Firmness

\section{* CORRESPONDING}

elciny@ omu.edu.tr

\section{Introduction}

The lack of quality during the process fresh vegetables and fruit are presented from the market to consumers affects both domestic market and export negatively. This negative situation results in decrease in fresh fruit consumption. The most important factors which influence consumers' shopping attitudes for fresh products are taste, flavor, freshness, maturity, looking good and cleanliness (Altisent, 1991).

Agricultural products can be exposed to static or dynamic forces during harvest or postharvest processes. Static or dynamic forces can affect taste, color and smell properties in products and cause loss in quality and value. Biological materials under static or dynamic force show some typical behaviors depending on their structural properties. While the compressive force applied causes the material to shorten, tensile force causes it to elongate. With the help of forcedeformation curve, mechanical properties of the material such as biological yield point, rupture point and the forcedeformation and energy values formed up to these points can be determined (Alayunt, 2000).

There are two important points in force-deformation curve. These are biological yield point and biological rupture point. Biological yield point is the region on the curve where there is an increase or no change in deformation. The cell is not harmed before biological yield point. However, at this point, intracellular ruptures occur in the material. Rupture point is the point on which the material under load is broken, cracked or degraded. After this point, it can be seen that deformation increases rapidly, whereas there is a rapid decrease in force (Mohsenin, 1970). It is important to know this point where the load carrying capacity is maximum.

Pear fruit is very sensitive to mechanical damage. Damage to pear fruit causes disease and deterioration during storage. This situation affects the product quality negatively and decreases the market value. Determination of rupture force, rupture energy, deformation and firmness values, which is the mechanical property of the 'Deveci' cultivar, helps to determine the resistance of the fruit to mechanical load and to take necessary measures accordingly.

Pear, which can be grown in temperate climate zone, is a kind of widely produced and consumed fruit in the world and its cultural history goes back to very old times. It belongs to the genus Pyrus from the Pomoideae sub-family of the Roseaceae family of Rosales. Turkey, which is the gene center of a great number of fruit varieties, is also among the native lands of pear. More than 600 varieties of pear are grown in many parts of Turkey (Özrenk et al., 2010). Pear is a fruit with economic importance which is both consumed fresh and also used in the production of puree, concentrate, nectar, clear pear juice and pulp pear juice mixtures and in addition some of it is processed and dried as canned food. It is estimated that the number of pear varieties in the world is more than 5000, while the number of those grown in Turkey is around 640 (Er, 2008). Pear is the second most important pome fruit after the apple in Turkey and Deveci pear cultivar is the main produced the best winter-typed cultivar about $20 \%$ of Turkey pear production quantity. Thus, Deveci pear cultivar has an important place of the pear production and growing in Turkey (Ozturk and Ozturk, 2014).

Nabizadeh and Esmaili (2007) examined the changes in the tissue of Golden Delicious variety apple fruit in terms of harvest date and storage period. Chemical analysis, penetration and uniaxial compression tests were applied to apple fruit in the study. The samples were collected on five harvest dates between September 17 and October 15 . According to the results of penetration tests, it was found that there was a decrease in crispiness (peak count), fracturability, hardness and toughness values as the storage 
period increased. According to compression test results, modulus of elasticity was also found to show the same disposition. It was concluded that early harvesting of apples protected the fruit tissue.

In a study conducted by Yahya et al. (2013) laboratory tests were conducted to investigate the properties of Jatropha curcas L. fruits obtained from trees of three planting densities namely 10880,5446 and 3630 plants acre1. In the study, physical and mechanical properties of the fruit were found. The properties included detachment force, rupture force, deformation at rupture point, deformation ratio at rupture point, hardness, energy used for rupture at both vertical and horizontal loading positions. Other properties studied were 1000-unit mass, dimensions, sphericity, bulk density, solid density, porosity, coefficient of static friction on plywood, steel and stainless steel. The lowest static friction coefficient of the fruit was found to be in stainless steel material. In the study, average detachment force and rupture force at vertical orientation values were found as $16.62 \mathrm{~N}$ and $57.17 \mathrm{~N}$. It was stated that mechanical properties showed statistically significant difference in terms of fruit orientations. As a conclusion, it was emphasized that physical and mechanical properties should be used in the design and development of harvesting and processing machines of Jatropha curcas L. fruit.

Chen et al. (1987) in their work, Chojuro, Twentieth Century, Tsu $\mathrm{Li}$ and $\mathrm{Ya} \mathrm{Li}$ Asian pear varieties applied compression and impact tests. They stored pears at $0^{\circ} \mathrm{C}$ and made measurements for 5 months in monthly periods. In addition, a certain number of pears were taken into the ripening room at $20^{\circ} \mathrm{C}$ in each measurement period and they were measured on the $2^{\text {nd }}$ and $4^{\text {th }}$ days. The maximum compression force value measured by this test was determined for the highest Chojuro variety. This value was about $32 \mathrm{~N}$ on the day harvested. The lowest value was about $24 \mathrm{~N}$ in the Twentieth Century cultivar. Chojuro and Twentieth Century varieties according to Tsu Li and $\mathrm{Ya} \mathrm{Li}$ varieties they have become softer and more resistant to damage with increased waiting time in the ripening room.

Knowing the physical and mechanical properties of agricultural products plays a significant and determining role in maintaining quality of product. In this study, mechanical properties of Deveci pear varieties harvested at different ripening periods were investigated. Rupture force, rupture energy, deformation and firmness values were determined on bloom side (B), lateral side (L) and stem side (S) location of pear fruit.

\section{Materials and methods}

'Deveci' pears cultivars used in the study and its fruits were harvested manually from SAMMEY fruit production farm in Samsun during the October in the commercial harvesting period. Before the measurements made under laboratory conditions, the pears were kept for an hour in $21 \pm 2^{\circ} \mathrm{C}$ temperature to reach the ambient temperature.

The moisture content of the fruits was determined by the oven method (Kachhadiya and Jethva, 2017) and were 75.48, $80.33,86.60$ percent (expressed in wet basis) for pears, respectively.

The pear size measurements in term of the major, intermediate and minor diameters were carried out with a digital caliper having an accuracy of $0.01 \mathrm{~mm}$. By using axis measurements, arithmetic mean diameter (Da), geometric mean diameter $(\mathrm{Dg})$ and sphericity values were calculated with the equations given (where; L major diameter, $\mathrm{mm}$; W intermediate diameter, $\mathrm{mm}$; $\mathrm{T}$ minor diameter, $\mathrm{mm}$ ) (Figure 1) (Mohsenin, 1970; 1980).

$$
\begin{gathered}
D_{a}=(L+W+T) / 3 \\
D_{g}=(L W T)^{1 / 3} \\
\phi=\frac{(L W T)^{1 / 3}}{L}
\end{gathered}
$$

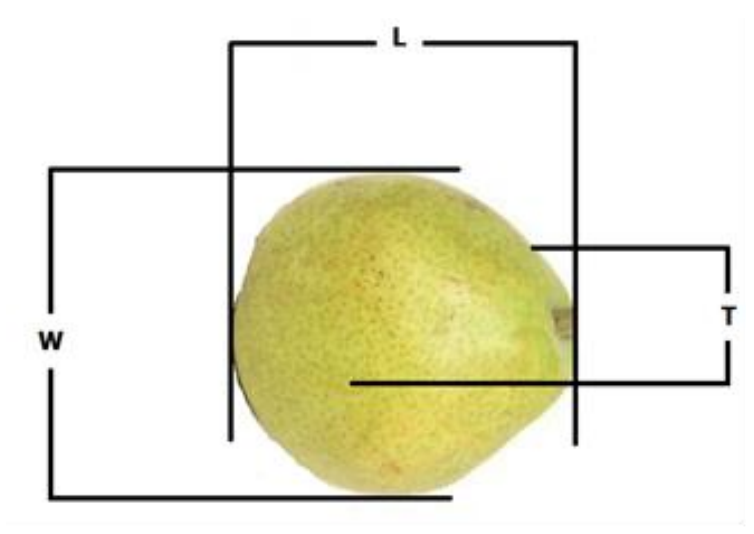

Figure 1. Sizes of pears

The following equation was used in finding out surface areas (Mohsenin, 1980).

$$
S=\pi D_{g}^{2}
$$

$\mathrm{S} \quad$ : Surface area $\left(\mathrm{mm}^{2}\right)$

Dg : Geometric mean diameter (mm).

The volume of the chestnut (V) was calculated from the following equation (Mohsenin, 1980):

$$
V=\frac{\pi}{6}(L W T)
$$

Atago Pocket make and PAL-1(Japan) model digital refractometer were used in finding out soluble solids content (SSC).

Mechanical properties of fruit were found by using LLoyd (Lloyd Instrument LRX Plus, Lloyd Instruments Ltd, An AMATEK Company) biological material testing device. Testing device consists of a platform on which the sample is put and a moving part, a movement unit and a data processing unit (Figure 2). Data processing unit has a load cell with $100 \mathrm{~N}$ capacity, and a computer with NEXYGEN Plus software to which the data is transferred. During the trials, a probe with a diameter of $10 \mathrm{~mm}$ was connected to the moving part and force was applied to the bloom side, lateral side and stem side of pears at $10 \mathrm{~mm} / \mathrm{min}$ compression speed (Yurtlu and Yesiloglu, 2012).

Force-deformation curve of the values obtained from load cell was formed through software program. The peak of force-deformation curve was determined as rupture force. 
Rupture energy was obtained with the calculation of the area under force-deformation curve. The values obtained from software program were recorded in file. Trials were conducted as 10 replicates.

Firmness was calculated by dividing the rupture force to the deformation in the rupture point (Yurtlu and Yesiloglu, 2012).
The effects of harvesting time and compression loading locations of fruit on rupture force, rupture energy, firmness and deformation were determined with ANOVA test. In addition, the difference between averages was shown statistically by using DUNCAN multiple comparison test.

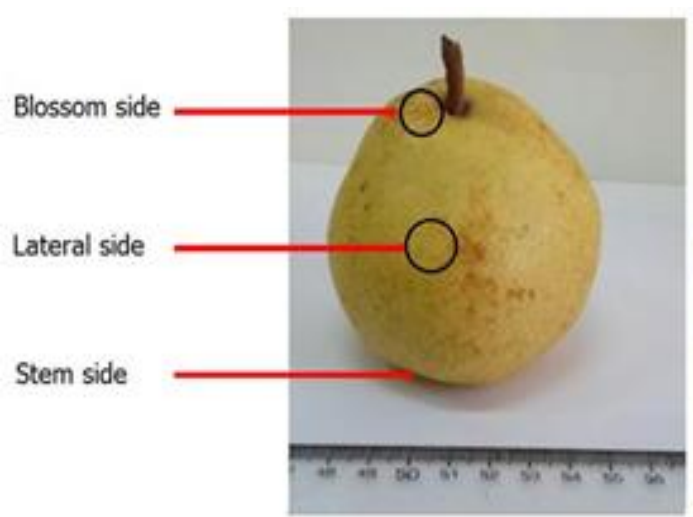

(a)

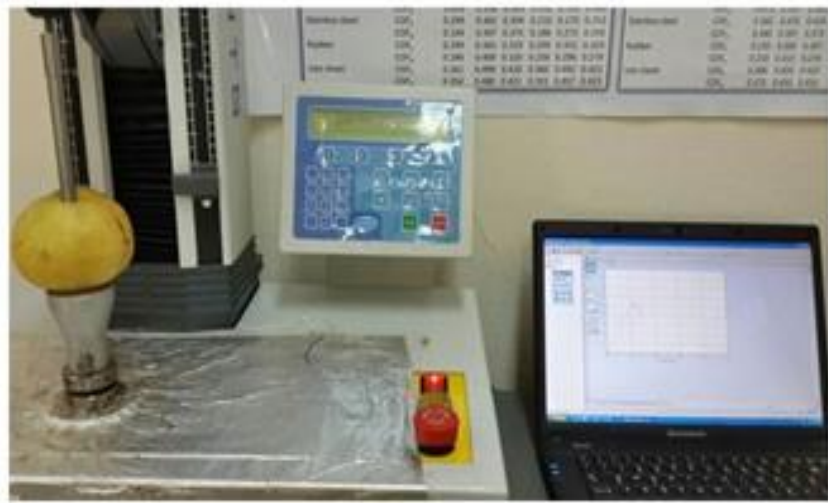

(b)

Figure 2. a - Representation of the three axes and three perpendicular dimensions of pear b - Lloyd Instrument universal testing machine

\section{Results and Discussion}

Average and standard deviation values of some physical properties of 'Deveci' pear cultivar used in the trials are given in Table 1.

The length dimension of 'Deveci' pear cultivar was found to be between 69.99 and 95.30, while its width dimension was found to be between 67.31 and 94.03 and its thickness dimension was found to be between 61.39 and $94.82 \mathrm{~mm}$. It was found that sphericity value differed between 0.84 and $1.20 \%$, while surface area value differed between 14740.54 and $26332.53 \mathrm{~mm} 2$, mass value differed between 181.81 and $360.15 \mathrm{~g}$, water soluble dry matter content differed between 7.6 and $15.7 \%$ and volume differed between 168284.37 and $4018902.50 \mathrm{~mm}^{3}$.

The effects of harvesting time and fruit sides on rupture force, rupture energy, firmness and deformation were examined and variance analysis results of these and $F$ values are given in Table 2 .

Table 1. Average and standard deviation values of physical properties of 'Deveci' pear cultivar

\begin{tabular}{|c|c|c|c|c|}
\hline & \multirow{2}{*}{ Properties } & \multicolumn{3}{|c|}{ Harvest Dates } \\
\hline & & 05 October & 15 October & 25 October \\
\hline \multirow{3}{*}{$\begin{array}{l}\text { Pear } \\
\text { dimension } \\
(\mathrm{mm})\end{array}$} & Major diameter (L) & $81.72 \pm 5.12$ & $82.83 \pm 3.42$ & $85.06 \pm 5.14$ \\
\hline & $\begin{array}{l}\text { Intermediate diameter } \\
\text { (W) }\end{array}$ & $73.97 \pm 3.08$ & $76.08 \pm 3.88$ & $86.18 \pm 4.91$ \\
\hline & Minor diameter $(\mathrm{T})$ & $71.03 \pm 3.73$ & $75.72 \pm 3.04$ & $82.69 \pm 4.67$ \\
\hline \multirow{2}{*}{$\begin{array}{l}\text { Average } \\
\text { diameter } \\
(\mathrm{mm})\end{array}$} & $\begin{array}{l}\text { Arithmetic mean } \\
(\mathrm{L}+\mathrm{W}+\mathrm{T}) / 3\end{array}$ & $75.58 \pm 2.92$ & $78.21 \pm 2.16$ & $59.60 \pm 2.51$ \\
\hline & $\begin{array}{l}\text { Geometric mean } \\
(\mathrm{LWT})^{1 / 3}\end{array}$ & $75.40 \pm 2.90$ & $78.10 \pm 2.17$ & $84.54 \pm 2.68$ \\
\hline \multicolumn{2}{|c|}{ Sphericity $(\%)$} & $0.92 \pm 0.04$ & $0.94 \pm 0.03$ & $0.99 \pm 0.06$ \\
\hline \multicolumn{2}{|c|}{ Surface area, $\mathrm{mm}^{2}$} & $17883.66 \pm 1366.69$ & $19176.53 \pm 1062.03$ & $22473.026 \pm 1417.05$ \\
\hline \multicolumn{2}{|c|}{ Mass $(g)$} & $213.96 \pm 17.82$ & $252.79 \pm 21.06$ & $308.22 \pm 23.92$ \\
\hline \multicolumn{2}{|c|}{ Soluble solids content (\%) } & $9.93 \pm 1.04$ & $10.37 \pm 0.54$ & $11.94 \pm 1.22$ \\
\hline \multicolumn{2}{|c|}{ Volume $\left(\mathrm{mm}^{3}\right)$} & $225360.98 \pm 25680.72$ & $249983.71 \pm 20701.93$ & $317242.88 \pm 29935.15$ \\
\hline \multicolumn{2}{|c|}{ Moisture Content w.b (\%) } & $75.48 \pm 1.41$ & $80.33 \pm 0.95$ & $86.60 \pm 0.71$ \\
\hline
\end{tabular}


Table 2. Measurement parameters and some statistical values

\begin{tabular}{|c|c|c|c|c|c|}
\hline Order of Harvesting & $\begin{array}{c}\text { Pear } \\
\text { locations }\end{array}$ & Rupture Force (N) & Deformation (mm) & $\begin{array}{c}\text { Rupture Energy } \\
(\mathrm{J})\end{array}$ & $\begin{array}{c}\text { Firmness } \\
(\mathrm{N} / \mathrm{mm})\end{array}$ \\
\hline \multirow{3}{*}{$\begin{array}{l}\text { First } \\
\text { (5 October) }\end{array}$} & $\mathrm{B}$ & $45.38 \pm 13.25$ & $5.40 \pm 1.39$ & $0.14 \pm 0.07$ & $8.54 \pm 2.02$ \\
\hline & $\mathrm{L}$ & $52.85 \pm 10.87$ & $5.49 \pm 0.68$ & $0.15 \pm 0.05$ & $9.69 \pm 1.83$ \\
\hline & $\mathrm{S}$ & $59.82 \pm 6.20$ & $5.82 \pm 1.00$ & $0.20 \pm 0.06$ & $10.53 \pm 1.95$ \\
\hline \multirow{3}{*}{$\begin{array}{l}\text { Second } \\
\text { (15 October) }\end{array}$} & $\mathrm{B}$ & $40.20 \pm 4.61$ & $4.96 \pm 1.00$ & $0.11 \pm 0.02$ & $8.42 \pm 1.99$ \\
\hline & $\mathrm{L}$ & $44.28 \pm 4.42$ & $5.02 \pm 0.59$ & $0.12 \pm 0.04$ & $8.92 \pm 1.37$ \\
\hline & $\mathrm{S}$ & $52.19 \pm 3.35$ & $5.70 \pm 0.56$ & $0.18 \pm 0.03$ & $9.22 \pm 0.99$ \\
\hline \multirow{3}{*}{$\begin{array}{l}\text { Third } \\
\text { (25 October) }\end{array}$} & $\mathrm{B}$ & $36.77 \pm 10.97$ & $4.87 \pm 1.12$ & $0.09 \pm 0.05$ & $7.62 \pm 1.12$ \\
\hline & $\mathrm{L}$ & $40.22 \pm 8.59$ & $4.93 \pm 0.98$ & $0.11 \pm 0.04$ & $7.76 \pm 1.68$ \\
\hline & $S$ & $48.09 \pm 8.52$ & $5.53 \pm 0.62$ & $0.14 \pm 0.03$ & $8.82 \pm 2.23$ \\
\hline \multicolumn{6}{|l|}{ Means } \\
\hline First Harvest & & $52.69^{c} \pm 11.98$ & $5.57^{\mathrm{b}} \pm 1.07$ & $0.16^{\mathrm{c}} \pm 0.06$ & $9.59^{c} \pm 2.09$ \\
\hline Second Harvest & & $45.56^{\mathrm{b}} \pm 6.38$ & $5.23^{\mathrm{a}} \pm 0.82$ & $0.14^{\mathrm{b}} \pm 0.04$ & $8.86^{\mathrm{b}} \pm 1.53$ \\
\hline \multirow[t]{4}{*}{ Third Harvest } & & $41.95^{\mathrm{a}} \pm 10.40$ & $5.12^{\mathrm{a}} \pm 0.96$ & $0.12^{\mathrm{a}} \pm 0.04$ & $8.09^{\mathrm{a}} \pm 0.96$ \\
\hline & $\mathrm{B}$ & $40.97^{\mathrm{a}} \pm 10.72$ & $5.09^{a} \pm 1.19$ & $0.12^{\mathrm{a}} \pm 0.05$ & $8.22^{\mathrm{a}} \pm 1.94$ \\
\hline & $\mathrm{L}$ & $45.85^{b} \pm 9.84$ & $5.15^{\mathrm{a}} \pm 0.79$ & $0.13^{\mathrm{a}} \pm 0.04$ & $8.80^{\mathrm{b}} \pm 1.81$ \\
\hline & $\mathrm{S}$ & $53.37^{\mathrm{c}} \pm 7.89$ & $5.69^{\mathrm{b}} \pm 0.76$ & $0.17^{\mathrm{b}} \pm 0.05$ & $9.52^{\mathrm{c}} \pm 1.93$ \\
\hline \multicolumn{6}{|l|}{$P$ values } \\
\hline Pear locations & & $\leq 0.001$ & $\leq 0.05$ & $\leq 0.001$ & $\leq 0.001$ \\
\hline Harvest Time & & $\leq 0.001$ & $\leq 0.001$ & $\leq 0.001$ & $\leq 0.001$ \\
\hline \multicolumn{6}{|c|}{ B: Bloom side $\quad$ L: Lateral side S: Stem side } \\
\hline
\end{tabular}

SAs can be seen in Table 2, the effect of fruit sides on rupture force, rupture energy and firmness was found to be statistically significant at the level of $1 \%(\mathrm{P} \leq 0.01)$ and their effect on deformation was found to be statistically significant at the level of $5 \%(\mathrm{P} \leq 0.05)$. The effect of harvesting time on rupture force, rupture energy, firmness and deformation were found to be significant at the level of $1 \% \quad(\mathrm{P} \leq 0.01)$. According to the results of Duncan multiple comparison test, while the values of rupture force, rupture energy, and firmness were found to be indifferent groups for all harvesting times, the values of second and third harvesting time related to deformation were found to be in the same group. While the values of rupture force and firmness were found to be indifferent groups for all fruit sides, the bloom side and lateral side values related with rupture energy and deformation were found to be in the same group. The decrease was found in rupture force, rupture energy, firmness and deformation values as harvesting time progressed.

The present study showed that firmness values of mature pear fruit were less. Firmness value was $9.59 \mathrm{~N} / \mathrm{mm}$ in the first harvesting date and $8.09 \mathrm{~N} / \mathrm{mm}$ in the third harvesting date. When firmness values were examined in terms of fruit sides, the stem side was found to have the highest value. The lowest firmness value was found in the bloom side.

When the harvesting dates were taken into consideration, it was found that the rupture force value, which is needed for the rupture of pear fruit peel, was the highest in the first harvesting date: Rupture force values were as 52.69, 45.56 and $41.95 \mathrm{~N}$ in the first, second and third harvesting dates, respectively. In terms of fruit sides, the highest rupture force was found in the stem side, while the lowest rupture force was found in the bloom side.In terms of harvesting dates, the highest value of rupture energy was found to occur in the first harvesting date. Rupture energy values were $0.16,0.14$ and $0.12 \mathrm{~J}$ in the first, second and third harvesting dates, respectively. In terms of fruit sides, rupture energy was found to be the lowest in the bloom side, while it was found to be the highest in the stem side. Rupture force values were as on the bloom side 40.97 , on the lateral side, 45.85 and on the stem side $53.37 \mathrm{~N}$ in the first, second and third harvesting dates, respectively.

Deformation in pear fruit was found to decrease as the harvesting date progressed. Deformation was 5.57 in the first harvesting date and as $5.12 \mathrm{~mm}$ in the third harvesting date. When deformation values were examined in terms of fruit sides, they were found to be the lowest in the bloom side and the highest in the stem side.

\section{Conclusion}

Firmness can be an indicator of fruit maturity. Firmness is an important parameter for measuring fruit hardness for postharvest processes. Since the pear fruits which are more mature have a softer texture, a decrease in hardness values has been determined. Similarly, a decrease in rupture force values was observed. Determining the appropriate harvest time is very important for the post-harvest evaluation of the fruits. Rupture force was found to be at highest system side and lowest bloom side. In the packaging of pear fruits, taking into account the regions of the fruit packaging will reduce the mechanical damage.

The present study determined some physical mechanical 
properties of commercially valuable 'Deveci' pear cultivar. With the data about determined properties, it will be possible to design tools, equipment and technological equipment, to minimize product losses and to increase and to improve efficiency.

\section{References}

Altisent, M. R. (1991). Damage mechanisms in the handling of fruits: Progress in agricultural physics and engineering. Commonwealth Agricultural Bureaux (CAB) International, Willingford, UK, 231-255.

Alayunt, F.N. (2000). Physical properties of biological materials. Ege University, Publication of Faculty of Agriculture No. 541, Izmir, Turkey, ISBN: 975-483-464-4.

Er, Ş. H. (2008). Researches on the biology of pear pest Cacopsylla pyri (L.) (Homoptera: Psyllidae) in the province of Ankara. Doctorate Thesis, Ankara University, Institute of Science Department of Plant Production, Ankara.

Ercisli, S. (2004). A short review of the fruit germplasm resources of Turkey. Genetic Resources and Crop Evolution, 51(4), 419-435.
Kachhadiya, S., \& Jethva, K. R. (2017). Physico-chemical properties of custard apple. International Journal of Biochemistry Research \& Review, 20(1), 1-13.

Mohsenin, N.N. (1970). Physical properties of plant and animal material. Gordon and Breach. New York.

Mohsenin, N. N. (1980). Physical properties of plant and animal material. Gordon and Breach Science Publishers Inc., New York, USA.

Nabizadeh, F., \& Esmaiili, M. (2007). Mechanical properties of golden delicious apple affected by maturation and storage. Food Engineering, 78, 622.

Ozturk, A. and Ozturk, B. (2014). The rootstock influences growth and development of 'Deveci' pear. Turkish Journal of Agricultural and Natural Sciences, (Special Issue), 1, 1049-1053

Yahya, A., K. Hamdan, T. A. Ishola and H. Suryanto. (2013). Physical and mechanical properties of Jatropha curcas 1 . fruits from different planting densities. Journal of Applied Sciences 13(7), 1004-1012.

Yurtlu, Y. B, Yeşiloğlu, E (2012). Mechanical behaviour and split resistance of chestnut under compressive loading. Journal of Agricultural Sciences 17(4), 337-346. 